\title{
Potensi padung-padung sebagai alternatif elemen estetik pada pengembangan desain produk kontemporer
}

\author{
Ariani* $^{*}$ \\ Program Studi Desain Produk, FSRD Universitas Trisakti, Jakarta, Indonesia
}

\begin{abstract}
Karo tribe in North Sumatra as one of the ethnic variety in the archipelago has its own art and cultural heritage, one of which is a unique jewelry called padung-padung. This jewelry was used by Karo women in the past as jewelry as well as status symbol. Currently, padung-padung completely no longer used, even many Karo people, especially younger generation, do not know it. The strong influence of foreign culture due to the advancement of technology has become one of the reasons for the increasingly displaced padung-padung. This article is a summary of the result of previous research that aims to re-examine the existence of padung-padung in the past, identify the meaning and role and cause of the loss of padung-padung from the life of Karo tribe. In addition, this study also aims to explore the potential of padung-padung as an alternative aesthetic elements in the development of contemporary product design in order to preserve the diversity of art and culture of Indonesia.
\end{abstract}

Keywords: padung-padung, nine elements of artifact forming, aesthetic element, contemporary product design.

\begin{abstract}
Abstrak
Suku Karo di Sumatera Utara sebagai salah satu dari beragam etnik yang ada di Nusantara memiliki warisan seni dan budaya tersendiri, salah satunya adalah perhiasan unik yang disebut padung-padung. Perhiasan ini digunakan wanita Karo pada masa lalu sebagai perhiasan sekaligus simbol status. Saat ini, padung-padung sama sekali tidak lagi digunakan, bahkan banyak masyarakat Karo terutama generasi mudanya yang tidak mengenalnya. Kuatnya pengaruh budaya luar akibat semakin majunya teknologi menjadi salah satu sebab semakin tergesernya padung-padung. Artikel ini adalah ringkasan dari hasil penelitian sebelumnya yang bertujuan untuk menelisik kembali keberadaan padung-padung di masa lalu, mengidentifikasi makna dan perannya serta penyebab hilangnya padung- padung dari kehidupan suku Karo. Di samping itu, penelitian ini juga bertujuan menggali potensi padung-padung sebagai alternatif elemen estetik pada pengembangan desain produk kontemporer dalam rangka melestarikan keragaman seni dan budaya Indonesia.
\end{abstract}

Kata kunci: padung-padung, sembilan elemen terbentuknya artefak, elemen estetis, desain produk kontemporer

\section{Pendahuluan}

Suku Karo di Sumatera Utara sebagai salah satu dari beragam etnik yang ada di Nusantara memiliki warisan seni dan budaya tersendiri, salah satunya adalah perhiasan unik yang disebut padung-padung. Padungpadung adalah sejenis anting-anting yang terbuat dari emas dan perak dan memiliki ukuran cukup besar dengan berat berkisar $1.5-2 \mathrm{~kg}$. Padung-padung digunakan dengan cara dimasukkan ke dalam lubang di daun telinga dan salah satu ujungnya dikaitkan pada kain penutup kepala. Perhiasan ini digunakan wanita
Karo pada masa lalu sebagai perhiasan sekaligus simbol status.

Saat ini, padung-padung sama sekali tidak lagi digunakan, bahkan banyak masyarakat Karo terutama generasi mudanya yang tidak mengenalnya. Kuatnya pengaruh budaya luar akibat semakin majunya teknologi menjadi salah satu sebab semakin tergesernya padung-padung. Potensi dan pengembangan seni budaya Karo tidak bisa terlepaskan dari bagaimana masyarakat Karo dalam mengapresiasikan kesenian Karo itu sendiri. Artikel ini adalah ringkasan dari hasil penelitian sebelumnya yang bertujuan untuk menelisik kembali keberadaan

\footnotetext{
* Koresponden penulis e-mail: arravqa@gmail.com
} 
padung-padung di masa lalu, mengidentifikasi makna dan perannya serta penyebab hilangnya padungpadung dari kehidupan suku Karo. Di samping itu, penelitian ini juga bertujuan menggali potensi padungpadung sebagai alternatif elemen estetik pada pengembangan desain produk kontemporer dalam rangka melestarikan keragaman seni dan budaya Indonesia.

Salah satu warisan nenek moyang yang sudah ditinggalkan adalah Padung. Padung adalah perhiasan berupa anting-anting (kerabu) yang digunakan oleh wanita Karo di masa lalu. Beberapa jenis padung yang dikenal adalah: padung raja mehuli, padung curu-curu (raga-raga), kudung-kudung, dan padung-padung. Pokok bahasan dalam penelitian ini adalah antinganting jenis padung-padung. Keunikan perhiasan yang terbuat dari emas dan perak ini adalah cara pemakaiannya yaitu dengan cara dimasukkan ke dalam lubang di daun telinga dan salah satu ujungnya dikaitkan pada kain penutup kepala (Sitepu, 2015).

Pembahasan padung-padung dari sisi estetika tentu tidak akan lepas dari ragam hias yang ada pada perhiasan tersebut. Beberapa dari ragam hias Karo diciptakan berdasarkan dorongan pengaruh luar seperti alam, binatang dan tumbuh-tumbuhan; hal ini dapat dilihat pada nama dan bentuk (motif) ragam hias tersebut diantaranya ragam hias ipen-ipen, keret-keret ketadu, lipan nangkih tongkeh, embun sikawiten, cekilikambing, pucuk tenggiang, bunga lawangdan lain-lain (Sitepu, 2015).

Semua karya seni rupa adalah artefak, teks, dan membenda. Karena membenda, maka sebuah karya seni yang diciptakan ratusan, bahkan ribuan tahun yang lampau sampai pada kita sekarang. Karena bendabenda seni masa lampau itu mengkomunikasikan gagasan dan pengalaman, maka alamat komunikannya adalah masyarakat zamannya pula. Kita, di zaman sekarang memiliki cara berpikir sendiri, yaitu cara berpikir manusia modern yang banyak kita terima dari masyarakat Barat. Kita seringkali menyingkirkan benda-benda seni tua karena tidak ada relevansinya lagi untuk hidup kesenian sekarang. Ini disebabkan cara membaca bahasa seni mereka adalah dengan menggunakan cara kita sekarang. Kalaupun ada bendabenda seni masa lampau yang masih memiliki daya tarik pada masa sekarang, maka daya tarik itu lebih disebabkan karena karya-karya itu masih terbaca dalam cara kita (Sumardjo, 2006).

Dalam budaya kontemporer, desain kontemporer berkembang pesat sejalan dengan perkembangan masyarakat urban (perkotaan). Desain urban diperkenalkan oleh V. Gordon Childe di tahun 1950. Childe mensintesakan data arkeologi untuk mengembangkan konsep urbanisme, dan mengenali transformasi sosial radikal yang menjadi asal usul perkotaan dan kawasan (Smith, 2009). Konsep desain urban ini menitikberatkan pada upaya menyesuaikan kawasan dan perkotaan untuk memenuhi kebutuhan masyarakat penggunanya, baik yang berkunjung maupun yang tinggal dan bekerja di tempat tersebut. Pengunjung dan masyarakat yang tinggal dan bekerja di kawasan dan perkotaan tersebut, tentunya memiliki struktur kebutuhan dasar sampai kebutuhan untuk mengaktualiasasi diri. Untuk memenuhi kebutuhan tersebut, para desainer menghubungkan konsep desain produk dengan konsep desain urban, untuk menciptakan desain produk yang memiliki citarasa perkotaan dan dibutuhkan oleh masyarakat urban.

Dalam fenomena desain sebagai suatu proses membendanya suatu gagasan, estetika senantiasa hadir dalam suatu sistem kolaborasi dengan aspek-aspek sebagai berikut:

1. Terjadi suatu proses interaksi antara objek tersebut dengan manusia pemakainya: objek memancarkan stimulus-stimulus (biophysics, psycho, socio culture spiritual) dan stimulusstimulus tersebut ditangkap oleh perangkat 5 (lima) indera manusia dan diinterpretasikan olehnya sesuai dengan world view, situasi, dan kepentingan manusia yang bersangkutan (biophysics, psycho, socio culture spiritual).

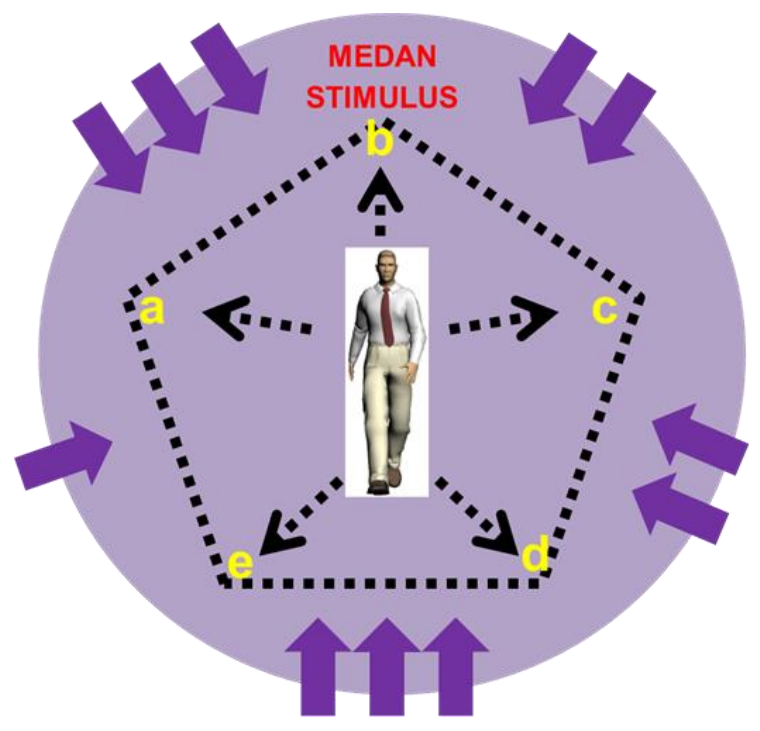

Gambar 1. Medan Indera Manusia (Sumber: Joedawinata, 2010)

2. Terdapat kandungan-kandungan: nilai-nilai simbolik (status sosial/spiritual kosmologis), ekspresi-ekspresi estetik-artistik, dan fungsi guna-praktis utiliter 
3. Unsur-unsur desain visual (warna, titik, bentuk, tekstur dan sebagainya) pada kenyataan empiriknya tidak bisa memancarkan stimulus secara sendiri-sendiri, tapi senantiasa bersamasama, simultan dan bersifat gestalt.

4. Suatu gagasan estetik dari seorang seniman/desainer senantiasa diawali dengan proses penghayatan terhadap berbagai situasi dan kondisi dari dunia biophysics, psychologis, socio culture spiritual dari lingkungan, dimana manusia yang bersangkutan berada. Melalui proses interaksi manusia yang bersangkutan meresponnya secara mental (psycho, socio culture spiritual). Atas dasar itu, muncullah berbagai need, will, dan fear dari yang bersangkutan yang ditransformasikan menjadi gagasan artistik dalam bidang seni rupa kriya dan desain yang bersifat mental dan abstrak.

5. Agar gagasan artistik yang abstrak tersebut bisa dijadikan objek-objek yang membenda (konkrit), maka gagasan artistik tersebut harus dipadukan dengan unsur-unsur material, teknik dan energi.

6. Karena luasnya kawasan, lokasi georafis yang khusus serta panjangnya peristiwa sejarah, maka setiap unsur-unsur pembentuk terwujudnya gagasan maupun objek-objek tersebut, pada dasarnya bersifat unik.

7. Dalam peristilahan pengembangan, senantiasa harus diformulasikan aspek-aspek yang berkaitan dengan: asalnya bagaimana, kemudian akan berkembang menjadi bagaimana, dan unsur-unsur pembentuk apa saja yang bisa tetap-berubah-hilang-atau digantikan menjadi unsur yang sama sekali baru.

8. Pengembangan yang dilakukan pada dasarnya mengacu pada unsur-unsur yang akan tetap, baru dan berubah yang mana dari aspek-aspek material-teknis-energi-guna-artistik serta ekonomis yang pada kenyataannya saling berkaitan mempengaruhi dalam proses perwujudan gagasan artistik yang konseptual menjadi objek yang membenda (Joedawinata, 2010).

Berdasarkan pemaparan di atas, dapat disimpulkan bahwa sifat saling mempengaruhi di antara beberapa unsur-unsur yang berkolaborasi seperti yang telah disebutkan di atas, akhirnya akan membentuk terwujudnya desain yang baik. Hal tersebut dapat dilihat pada skema yang tampak pada Gambar 2 .

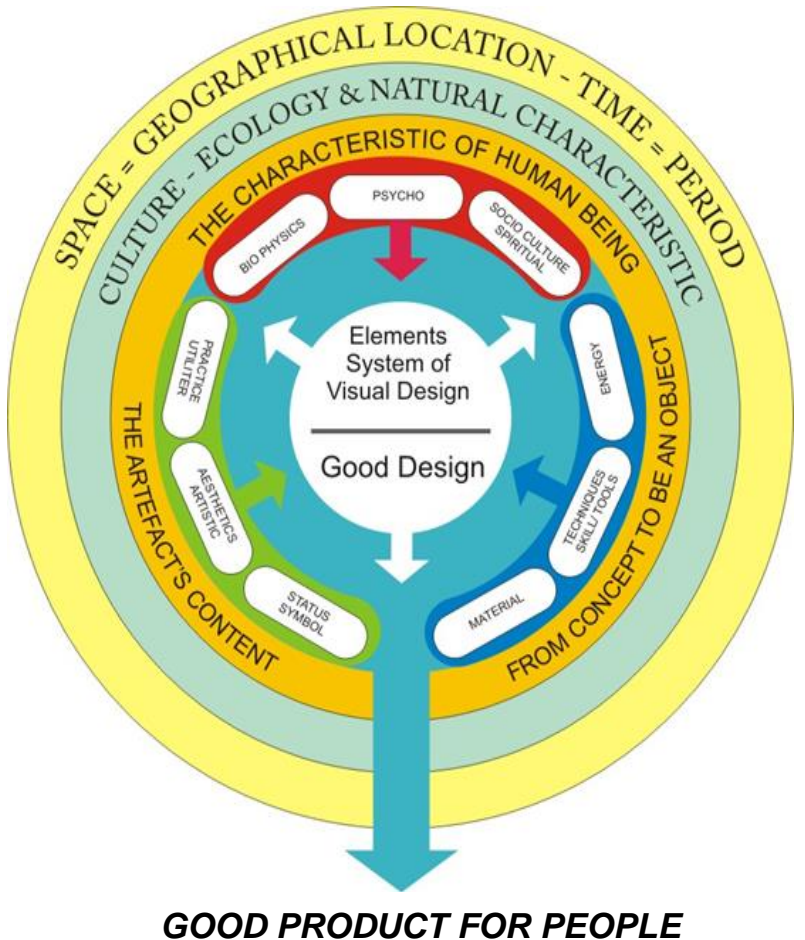

Gambar 2. Skema mind mapping design (Sumber: Joedawinata, 2008)

\section{Bahan dan Metode}

Artikel ini adalah ringkasan dari penelitian kualitatif yang menggunakan pendekatan hermeneutika untuk menganalisis sembilan unsur pemandu terbentuk dan berkembangnya objek artefak. Pendekatan hermeneutika yang digunakan adalah mengacu dari pendapat Paul Ricouer. Ricouer menyatakan tidak ada kebenaran mutlak dalam soal penafsiran atas sebuah wacana. Pemaknaan atau penafsiran selalu diantarai oleh sederet penanda dan teks. Dengan demikian, tugas hermeneutika tidak mencari kesamaan antara penyampai pesan (teks) dan penafsir, namun menafsirkan makna dan pesan se-objektif mungkin sesuai dengan yang teks yang ada. Teks itu sendiri tentu saja tidak terbatas pada bukti tertulis atau gambar visual, tetapi selalu berkaitan dengan konteks. Di dalam konteks terdapat berbagai aspek yang bisa mendukung keutuhan pemaknaan. Analisis harus selalu bergerak dari teks, bukan dari hal-hal lain di luar teks. Hal terpenting dari semua itu adalah bahwa proses penafsiran selalu merupakan dialog antara teks dan penafsir (Ricoeur, 2003).

Di samping menggunakan pendekatan hermeneutika, penelitian ini akan menggunakan metode eksperimentatif untuk menggali potensi 
padung-padung yang akan diterapkan dalam desaindesain produk kontemporer saat ini, seperti desain fashion (perhiasan) dan desain cinderamata (souvenir) sebagai upaya untuk melestarikan keragaman seni dan budaya Indonesia. Dengan demikian, objek penelitian dalam hal ini adalah padung-padung, dianalisis berdasarkan 9 unsur pemandu terbentuk dan berkembangnya objek artefak. Sembilan unsur tersebut terdiri dari bio physics, sosio culture spiritual pada penggunanya, psikologi, fungsi, citra estetik artistik, simbol status, material, teknik, dan energi yang digunakan (Joedawinata, 2011).

\section{Hasil dan pembahasan}

Penjabaran dari analisis berdasarkan 9 unsur tersebut dikemukakan pada paragraph-paragraf berikut.

Bio Physics. Kehidupan kelompok etnis Karo tidak terlepas dari kebudayaannya karena kebudayaan ada karena ada masyarakat pendukungnya. Sebagai masyarakat yang tinggal di wilayah pedalaman dataran tinggi Karo dan sekitarnya, ternyata selain sebagai sebuah komunitas, terbentuk juga sebuah budaya yang menjadi pola (konsep dasar) bagi masyarakat Karo dalam berhubungan dengan sang pencipta alam berserta isinya begitu pula hubungan antara masyarakat didalamnya. Pola hubungan tersebut dalam sebuah aturan tidak tertulis yang mengatur disebut dengan budaya. Berikut ini akan dijelaskan hal-hal yang berkaitan dengan kebudayaan suku Karo, kesenian Karo, dan padung-padung.

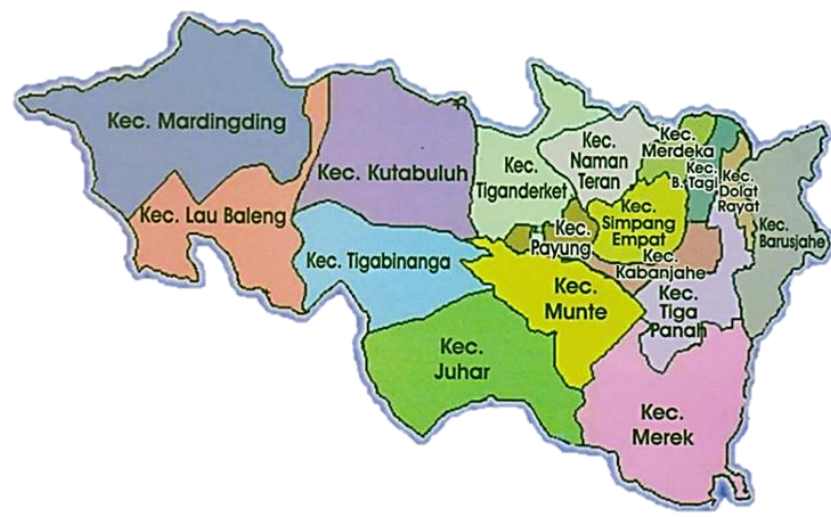

Gambar 3. Peta daerah Kabupaten Karo

(Sumber: Pemerintah Daerah kabupaten Karo, Sumatera Utara, 21 April 2015)

Kedekatan masyarakat Karo dengan alam menjadi inspirasi bagi mereka dalam banyak hal. Salah satunya adalah bentuk padung-padung yang diambil dari motif binatang yaitu jenis serangga yang disebut tanggatangga atau dalam bahasa Indonesia disebut kaki seribu (Chilognata) (lihat Gambar 4).

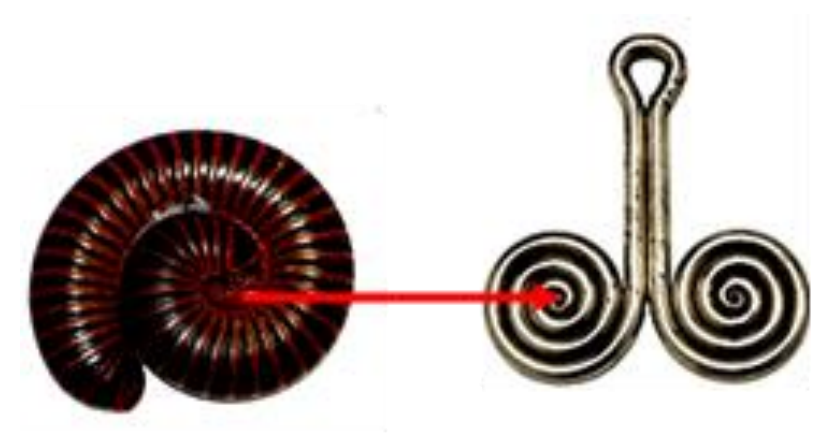

Gambar 4. Serangga kaki seribu yang sedang menggulung (kiri) menjadi inspirasi bentuk padung-padung (kanan)

(Sumber: http://id.wikipedia.org/wiki/Kaki_seribu, Oktober 2015 dan Museum Pusaka Karo, Juli 2015)

Struktur bentuk padung-padung yang diadaptasi dari bentuk serangga kaki seribu yang sedang bergulung menyerupai spiral tersebut terlihat sangat sederhana dibandingkan perhiasan-perhiasan lain yang kaya akan ornamen dan ragam hias pada masa itu. Suku Karo sendiri memiliki beragam jenis ornamen (ragam hias) yang awalnya adalah seni ukir dan telah diterapkan pada beberapa bentuk karya-karya seni dan benda-benda pakai. Bentuk ragam hias itu sebagian tercipta atas dorongan dan pengaruh lingkungan alam, manusia, binatang, dan tumbuh-tumbuhan. Bentuk geometris padung-padung merupakan penerapan dari salah satu ornamen Karo yaitu panai yang berfungsi sebagai penolak bala, mengusir roh jahat, dan ngenen gereken-gereken (melihat suatu firasat).

Sosio Culture Spiritual. Pengaruh Hindu terhadap kehidupan suku Karo sangat kuat dan dijumpai pada kebiasaan-kebiasaan yang masih terus berlangsung hingga saat ini. Pengaruh Hindu tersebut dibawa oleh imigran dari India yang pada masa itu bekerja untuk Belanda di perkebunan-perkebunan. Mereka sering disapa si Mbiring (si Hitam). Akhirnya pengucapan si Mbiring berubah menjadi Sembiring dan kemudian marga yang kedudukannya sama dengan marga induk. Selain dalam hal kepercayaan, pengaruh Hindu tampak pada merga-merga suku Karo seperti Pandya, Depary, Teykang, Maylialam, Maha, Muham, Colya, dan lainlain yang diambil dari bahasa Sansekerta. Hingga kini, di kota Medan masih banyak dijumpai etnis India atau Tamil yang hidup berdampingan dengan suku-suku lainnya.

Psikologi. Dari berbagai aspek kehidupan masyarakat tampak bahwa penempatan peran gender terhadap kaum wanita lebih terpusat pada sektor 
domestik. Fenomena umum yang demikian merupakan implikasi dari pemosisian wanita berdasarkan paradigma sosio-kultural dan konstruksi sosial dari masing-masing masyarakat. Wanita Karo hanya memiliki wilayah kekuasaan di sektor domestik tanpa adanya campur tangan dari kaum pria (dianggap tabu). Pembatasan terhadap wilayah kekuasaan wanita di lingkungan reproduksi atau sektor domestik merupakan suatu pemisahan antara peran pria dengan peran wanita.

Fungsi. Berekspresi melalui kesenian merupakan salah satu aktivitas manusia yang sangat umum dalam kehidupan bermasyarakat. Dengan demikian kesenian merupakan suatu kebutuhan yang penting dalam sebuah masyarakat untuk mengekspresikan dirinya sebagai manusia yang memiliki perasaan indah, senang, gembira, maupun sedih. Hal ini juga yang terjadi pada masyarakat Karo. Dengan kondisi tanah yang subur dan lingkungan yang sejuk, tanah Karo tempat masyarakat Karo tinggal merupakan 'surga dunia' dan ini berkembang hingga menjadi sebuah komunitas. Komunitas Karo memiliki bahasa dan cara bertutur yang khas, rumah adat yang kokoh, adat istiadat yang bertabur emas, alat musik tradisional yang khas dan juga hasil pemikiran yang cermat seperti permainan catur Karo. Pada aspek fungsi, akan dibahas fungsi padung-padung dalam wujud fisik (tangible) sebagai sebuah perhiasan, dimana perhiasan suku Karo merupakan salah satu identitas budaya di antara kekayaan seni tradisional suku Karo yang lain.

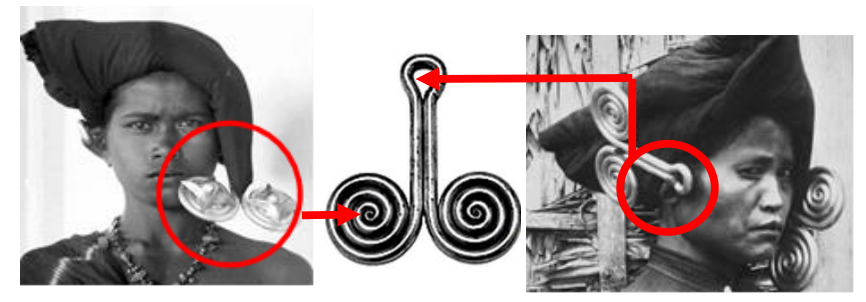

Gambar 5. Padung-padung dengan ornamen di bagian tengahnya (kiri) dan jenis padung-padung yang lain yang dikenakan wanita Karo dewasa (kanan).

(Sumber: Siadi, 2015)

Padung-padung adalah perhiasan yang digunakan wanita suku Karo pada akhir abad 19 sampai dengan awal abad ke 20 (Sibeth, 1991). Perhiasan berbentuk anting-anting ini ada yang terbuat dari perak dan terkadang dari emas jenis suasa, memiliki panjangnya berkisar antara $7.5 \mathrm{~cm}, 13 \mathrm{~cm}$, dan 15,5 cm. dengan berat sekitar 1,5-2 kg (Sibeth, 1991). Penggunaaan padung-padung adalah dengan cara memasukkan salah satu bagian ke dalam lubang daun telinga kemudian salah satu bagian yang lain dikaitkan ke tudung atau kain penutup kepala (Gambar 5). Dengan demikian beban padung-padung yang cukup berat tersebut menjadi berkurang.

Citra Estetik Artistik. Ada 3 aspek dasar yang akan dianalisis dari sisi citra estetik artistik ini, yaitu wujud, bobot, dan penampilan. Dilihat dari struktur pembentuknya, padung-padung seperti yang telah dijelaskan sebelumnya, mengadaptasi bentuk serangga kaki seribu yang sedang bergulung. Bentuk yang menyerupai spiral tersebut terlihat sangat sederhana dibandingkan perhiasan-perhiasan lain yang kaya akan ornamen dan ragam hias pada masa itu. Namun, justru karena wujud yang sederhana tanpa banyak ornamen dan detail di dalamnya itulah yang menyebabkan padung-padung menjadi sebuah perhiasan yang unik. Karakter material yang digunakan juga terlihat menonjol. Kesederhanaan bentuk padung-padung menjadi daya tarik di antara perhiasan-perhiasan lain, tidak hanya di masa perhiasan tersebut masih dipakai, namun hingga kini ketika bentuknya hanya dapat dikenali melalui wujud visual berupa foto-foto dokumentasi. Keindahan padung-padung justru muncul di balik kesederhanaan tersebut. Selain bentuk spiral yang sederhana pada padung-padung ternyata ditemukan juga padung-padung dengan ornamen di atasnya. Hal ini terjadi karena permintaan para pemesannya yang menginginkan desain yang berbeda pada padung-padung yang akan dikenakannya dan biasanya bahan bakunya disediakan oleh pemesan tersebut (Sibeth, 1991).

Citra estetik artistik yang kedua adalah bobot. Bobot yang dimaksudkan di sini bukan berat padung-padung, namun meliputi apa yang bisa dirasakan atau dihayati sebagai makna dari wujud padung-padung. Di balik wujud padung-padung yang sederhana, tersimpan makna simbolik yang memiliki arti cukup dalam. Tidak hanya melambangkan kedekatan masyarakat Karo terhadap alam yang telah memberikan kehidupan layak kepada mereka, namun juga mengandung pesan dari seorang ayah sebagai bentuk kecintaannya kepada anak gadisnya yang akan menikah. Walaupun di dalam garis keturunan masyarakat Karo masih menganut sistem patrilineal, yang berarti anak laki-laki adalah penerus marga dalam keturunan mereka, namun bukan berarti anak perempuan tidak memiliki arti sama sekali. Padung-padung diberikan oleh seorang ayah kepada anak gadisnya pada hari pernikahannya sebagai lambang statusnya yang baru setelah menikah (Brinkgreve \& Stuart-Fox, 2013). Berdasarkan hal tersebut, dapat kita simpulkan bahwa walaupun di dalam garis keturunan masyarakat Karo masih menganut sistem patrilineal, yang berarti bahwa anak laki-laki adalah penerus marga dalam keturunan mereka, namun bukan berarti anak perempuan tidak memiliki arti sama sekali. Bentuk spiral memiliki 
makna yang cukup beragam. Jika dirangkum, makna simbolik spiral menggambarkan kekuatan matahari dan bulan, udara, air, guntur, dan kilat, pusaran, dan kekuatan kreatif. Secara kontradiktif, spiral juga menggambarkan naik dan turunnya matahari, pasang dan surutnya bulan, tumbuh-kembang-kematian, penyusutan, belitan dan bukaan, kelahiran dan kematian (Cooper, 1987). Dengan demikian, jika dikaji secara mendalam makna di balik pemberian padungpadung ini adalah bahwa sang ayah secara tidak langsung ingin menyampaikan pesan kepada anak gadisnya agar bijaksana dalam menyikapi berbagai permasalahan yang akan timbul dalam kehidupan perkawinannya. Pendapat lain menyatakan bahwa padung-padung diberikan sebagai hadiah dari keluarga pihak pengantin laki-laki kepada pengantin wanita (Rodgers, 1988). Cara pemakaian padung-padung berbeda antara telinga sebelah kanan dengan telinga sebelah kiri yaitu pada bagian telinga kanan di gunakan ke arah belakang dengan posisi agak naik dan pada telinga bagian kiri padung-padung menghadap ke depan dengan posisi lebih rendah. Hal ini ternyata mengandung makna implisit yang melambangkan kehidupan sebuah perkawinan yang tidak selamanya berjalan mulus. Selalu akan timbul kondisi yang senang (disimbolkan dengan posisi padung-padung ke atas) dan susah (disimbolkan dengan posisi padungpadung ke bawah). Oleh karena itu dalam sebuah kehidupan perkawinan, sepasang suami istri harus saling mendukung (Rodgers, 1988).

Citra estetik yang ketiga adalah penampilan. Selain mengenakan padung-padung, wanita Karo biasanya mengenakan perhiasan lain seperti gelang sarung, sertali layang-layang kitik, padung curu-curu, cincin pinta-pinta, dan sebagainya. Hal yang membuat padung-padung terlihat menonjol adalah ukurannya yang cukup besar untuk sebuah anting-anting. Selain faktor ukuran, cara pemakaiannya yang tidak lazim yaitu dikaitkan pada kain penutup kepala dan kesederhanaan bentuk juga menjadikan perhiasan ini terlihat unik dan indah. Pada saat dikenakan, padungpadung menjadi daya tarik bagi wanita yang mengenakannya. Bukan hanya dari segi ukurannya yang diluar kelaziman, namun bentuk dan cara menggunakannya pun berbeda dari perhiasan pada umumnya. Secara keseluruhan, wanita-wanita Karo yang mengenakan padung-padung menampilkan sisi eksotik kearifan lokal budaya Karo sehingga dipilih untuk diabadikan menjadi sampul beberapa buku yang diterbitkan di luar negeri.
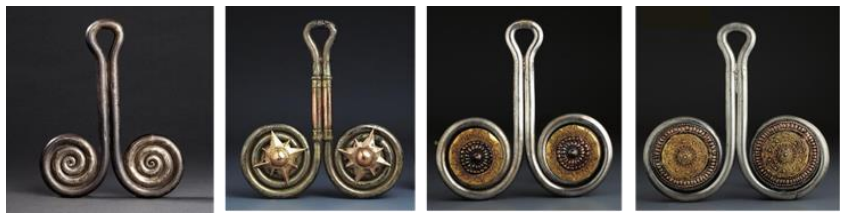

Gambar 6 (dari kiri ke kanan). Padung-padung tanpa ragam hias. Material terbuat dari perak disepuh emas atau suasa atau perak tanpa sepuhan, berat 1,5-2 kg, panjang $15,5 \mathrm{~cm}$, menggunakan bentuk bintang sebagai ornamen, ada juga yang menggunakan teknik granulasi pada bagian ornamen. (Sumber: Barbier-Muller, dkk, 1988)

Simbol Status. Simbol status diartikan sebagai kepemilikan yang dianggap sebagai bukti dari posisi sosial, kekayaan, prestis dari seseorang. Simbol status juga dapat diartikan sebagai posisi sosial seseorang berdasarkan status sosial atau ekonominya (Cherrington, 1994). Padung-padung merupakan simbol status bagi mereka yang menggunakannya, karena hanya wanita yang berasal dari keluarga yang memiliki peran penting di sebuah desa yang bisa memilikinya. Padung-padung melambangkan status sosial dan kekayaan pemakainya. Hanya perempuan suku Karo kelas atas (perempuan yang mewakili garis keturunannya yaitu yang nenek moyangnya adalah pendiri desa atau orang penting di sebuah desa) dan berasal dari golongan mampu yang biasa memakainya. Hal tersebut dapat dilihat dari material yang digunakan sebagai bahan baku untuk membuat padung-padung, yaitu emas jenis suasa dan perak, tentunya perhiasan ini memiliki nilai yang cukup mahal. Dengan demikian, dapat disimpulkan bahwa perhiasan ini selain dimiliki oleh wanita dari keluarga kepala desa atau sesepuh adat, ternyata juga dimiliki oleh orang dari golongan masyarakat yang memang mampu secara ekonomi pada masa itu. Di samping itu, ditemukan fakta berdasarkan pengamatan dari fotofoto dan ukuran padung-padung yang bervariasi (besar, sedang, kecil) bahwa padung-padung tidak hanya digunakan oleh wanita dewasa, tetapi juga anakanak dan remaja.

Material. Material yang digunakan untuk membuat padung-padung adalah emas jenis suasa dan perak. Anting-anting ini ada juga yang terbuat dari perpaduan perak dan sering dihiasi dengan cakram tambahan emas dan suasa (paduan emas dan tembaga). Di antara jenis-jenis material logam yang lain, dua material ini termasuk ke dalam golongan logam mulia yang artinya memiliki ketahanan tinggi terhadap korosi atau karat. Emas adalah material yang memiliki karakter lunak, padat, dapat ditempa, elastis, dan konduktif. Sedangkan perak memiliki daya konduktivitas tertinggi di antara jenis logam lainnya dan tingkat kilap 
yang tinggi. Baik emas maupun perak, biasa digunakan sebagai bahan baku untuk membuat perhiasan, uang logam, dan bagian dari komponen elektronik (Cuffaro, 2006).

Teknik. Masyarakat Karo memiliki kemampuan dan keahlian yang sangat baik dalam mengolah logam menjadi perhiasan dan benda-benda lain dalam keseharian mereka. Ditinjau dari bentuknya, teknik pembuatan padung-padung adalah dengan cara meleburkan material perak dan emas suasa (sebagian berasal dari uang logam) menjadi logam cair yang kemudian dicetak dalam bentuk logam batangan berbentuk silinder padat (solid metal). Selanjutnya logam silinder tersebut di bentuk melingkar menyerupai spiral yang merupakan adaptasi dari bentuk serangga kaki seribu yang sedang menggulung. Proses pembentukan padung-padung dilakukan dengan teknik bending, yaitu proses deformasi secara plastik dari logam terhadap sumbu linier dengan hanya sedikit atau hampir tidak mengalami perubahan perubahan luas permukaan. Bending menyebabkan logam pada sisi luar sumbu netral mengalami tarikan, sedangkan pada sisi lainnya mengalami tekanan. Proses ini menggunakan teknik hot working process (Sujarwanto, 2017).

Energi. Energi merupakan salah satu aspek yang dibutuhkan untuk mewujudkan ide/gagasan menjadi benda/produk. Pada pembuatan padung-padung ini, yang paling berperan adalah para pandai besi yang memiliki skill tinggi dalam mengolah logam dengan peralatan yang sangat sederhana pada masa itu. Perhiasan tersebut dibuat secara manual berdasarkan pesanan. Energi yang digunakan untuk mengolah dan membentuk logam adalah bara api yang berasal dari pembakaran arang.

\section{Potensi padung-padung sebagai alternatif elemen estetik pada pengembangan desain produk kontemporer}

Modernisasi adalah salah satu yang menjadi penyebab menghilangnya padung-padung dari keseharian para wanita Karo. Masuknya agama Islam dan Kristen pada abad ke-20 (sekitar tahun 1800-an) telah mempengaruhi kepercayaan sebagian besar masyarakat Karo. Mereka mulai memeluk agama tersebut dan megikuti ajaran-ajarannya. Hal ini juga yang turut mempengaruhi pandangan masyarakat Karo terhadap budaya mereka sehingga kebiasaan-kebiasaan yang selama ini mereka lakukan mulai ditinggalkan karena dianggap tidak sesuai ajaran agama. Cara berpakaian dan menghias diri pun mulai disesuaikan dengan ketentuan ajaran agama. Pemakaian padungpadung adalah salah satu yang perlahan-lahan mulai ditinggalkan. keseharian mereka.
Saat ini, padung-padung sudah tidak dikenakan oleh para wanita suku Karo. Padung-padung saat ini hanya bisa dilihat melalui gambar-gambar/foto-foto yang hampir semuanya diabadikan oleh orang-orang Belanda yang pada masa penjajahan banyak berdomisili di dataran tinggi Tanah Karo. Selain melalui gambar, wujud fisik padung-padung dapat dilihat di beberapa museum yang ada di Tanah Karo yaitu museum Lingga di Kabanjahe dan museum Pusaka Karo di Berastagi serta museum-museum di luar negeri seperti di Mueller Museum di Jenewa (Perancis), Troppen Museum di Belanda, The Metropolitan Museum of Art di New York, Dallas Museum of Art di Dallas, dan beberapa museum di luar negeri lainnya.

Tabel 1. Padung-padung di Masa Lalu dan Sebagai Alternatif Elemen Estetik Aplikatif di Masa Kini

\begin{tabular}{|c|c|c|}
\hline No & $\begin{array}{l}\text { Padung-padung di } \\
\text { masa lalu }\end{array}$ & $\begin{array}{c}\text { Padung-padung Sebagai } \\
\text { Elemen Estetik pada Desain } \\
\text { Kontemporer }\end{array}$ \\
\hline 1. & $\begin{array}{l}\text { Memiliki berat } 1.5-2 \\
\mathrm{~kg}\end{array}$ & $\begin{array}{l}\text { Berat menyesuaikan dengan } \\
\text { kebutuhan dan kenyamanan } \\
\text { pengguna }\end{array}$ \\
\hline 2. & $\begin{array}{l}\text { Memiliki ukuran } 7.5 \\
\mathrm{~cm}, 13 \mathrm{~cm} \text {, dan } 15,5 \\
\mathrm{~cm}\end{array}$ & $\begin{array}{l}\text { Ukuran menyesuaikan dengan } \\
\text { kebutuhan }\end{array}$ \\
\hline 3. & $\begin{array}{l}\text { Terbuat dari perak } \\
\text { dan emas suasa yang } \\
\text { berbentuk padat } \\
\text { (solid metal) }\end{array}$ & $\begin{array}{l}\text { Tetap menggunakan material } \\
\text { emas dan perak jika akan } \\
\text { diaplikasikan sebagai perhiasan, } \\
\text { atau jenis material lain } \\
\text { tergantung kebutuhan dan selera } \\
\text { masyarakat }\end{array}$ \\
\hline 4. & $\begin{array}{l}\text { Berfungsi sebagai } \\
\text { perhiasan/asesoris } \\
\text { yaitu kerabu (anting- } \\
\text { anting) }\end{array}$ & $\begin{array}{l}\text { a. Tidak hanya berfungsi } \\
\text { sebagai anting-anting, namun } \\
\text { dapat menjadi alternatif } \\
\text { elemen desain pada jenis } \\
\text { perhiasan yang lain seperti } \\
\text { cincin, kalung, gelang, dsb } \\
\text { b. Dapat dikembangkan menjadi } \\
\text { desain souvenir yang } \\
\text { mengangkat identitas suku } \\
\text { Karo }\end{array}$ \\
\hline 5 & $\begin{array}{l}\text { Digunakan pada } \\
\text { pesta-pesta adat dan } \\
\text { keseharian wanita } \\
\text { Karo }\end{array}$ & $\begin{array}{l}\text { Pemakaian disesuaikan dengan } \\
\text { fungsinya }\end{array}$ \\
\hline 6. & $\begin{array}{l}\text { Memiliki makna } \\
\text { simbolik tentang } \\
\text { kehidupan khususnya } \\
\text { perkawinan }\end{array}$ & $\begin{array}{l}\text { Mewakili simbol kekayaan } \\
\text { budaya masyarakat Karo yang } \\
\text { tetap hidup di masa kini }\end{array}$ \\
\hline
\end{tabular}

Seperti yang telah disebutkan sebelumnya, salah satu upaya yang dapat dilakukan untuk mengangkat kembali keberadaan padung-padung agar dikenali oleh masyarakat luas khususnya generasi muda adalah dengan cara mengaplikasikan padung-padung pada desain-desain kontemporer, baik itu desain produk maupun tetap pada fungsinya sebagai perhiasan, 
tentunya dengan memperhatikan beberapa faktor. Beberapa faktor yang harus diperhatikan misalnya; berat, ukuran, material, fungsi, dan makna simbolik. Dengan memperhatikan faktor-faktor tersebut, bentuk padung-padung dapat diterapkan dalam berbagai macam desain produk, misalnya; sebagai souvenir, perhiasan, merchandise, dan produk-produk lainnya.

Dalam konteks pengembangan desain dengan menerapkan bentuk padung-padung sebagai salah satu elemennya, maka terlebih dahulu diperhatikan hal-hal berikut menyangkut padung-padung di masa lalu dan aplikasinya untuk masa kini seperti yang diperlihatkan dalam Tabel 1.

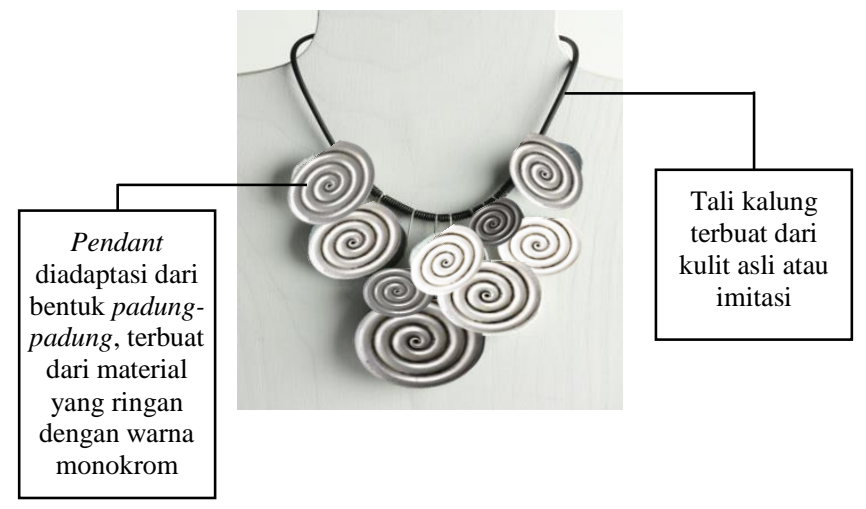

Gambar 7. Padung-padung diaplikasikan sebagai pendant/liontin

Salah satu momen yang tepat untuk memperkenalkan padung-padung misalnya adalah pada acara pagelaran peragaan busana, baik di tingkat internasional maupun nasional. Untuk memperkenalkan padung-padung melalui ajang pagelaran busana, ukuran, material, dan fungsi padung-padung disesuaikan dengan kebutuhannya. Dari segi ukuran, jika diterapkan sebagai anting-anting tentu tidak memungkinkan jika tetap mempertahankan ukuran aslinya karena terlalu besar sehingga tidak nyaman dan tidak praktis. Dari segi material, jika menggunakan ukuran dan material seperti aslinya (emas, perak, suasa solid) tentu akan terasa berat. Fungsi padung-padung sebagai anting-anting dapat tetap berfungsi sebagai anting-anting dengan ukuran dan material yang disesuaikan, namun dapat juga dikembangkan menjadi aksesori lain seperti kalung, gelang, ataupun cincin. Berikut adalah beberapa contoh pengembangan padung-padung sebagai asesoris yang melengkapi desain fashion.
Contoh desain kalung diperlihatkan oleh Gambar 7. Desain kalung tersebut mengaplikasikan salah satu sisi padung-padung yang menyerupai serangga kaki seribu sebagai pendant/leontin. Material yang digunakan adalah material dengan bobot yang ringan dan mudah dibentuk seperti rotan atau plastik. Warna yang digunakan adalah warna abu-abu monokrom yang menonjolkan kesan kontemporer. Tali kalung menggunakan material kulit asli atau kulit imitasi dengan warna hitam, senada dengan warna pendant/leontinnya. Contoh desain pada Gambar 7 tersebut masih dapat dikembangkan lebih jauh lagi menjadi berbagai jenis asesoris lain dengan pemahaman yang mendalam mengenai perhiasan kontemporer.

Selain desain fashion, padung-padung juga memiliki potensi sebagai inspirasi untuk desain cinderamata. Kabupaten Karo merupakan salah satu daerah tujuan wisata utama di Sumatera Utara yang memiliki potensi tidak kalah menarik dengan daerah tujuan wisata lainnya di Indonesia. Alternatif desain cinderamata yang dibuat akan didesain dengan menerapkan padung-padung di dalamnya baik dari segi bentuk maupun elemen visualnya. Tujuannya adalah agar cinderamata tersebut memiliki ciri khas daerah Karo sehingga wisatawan yang membelinya akan selalu mengingat keunikan padung-padung beserta Tanah Karo tempat dimana perhiasan tersebut berasal. Berikut ini adalah beberapa alternatif desain cinderamata yang merupakan aplikasi dari bentuk padung-padung.

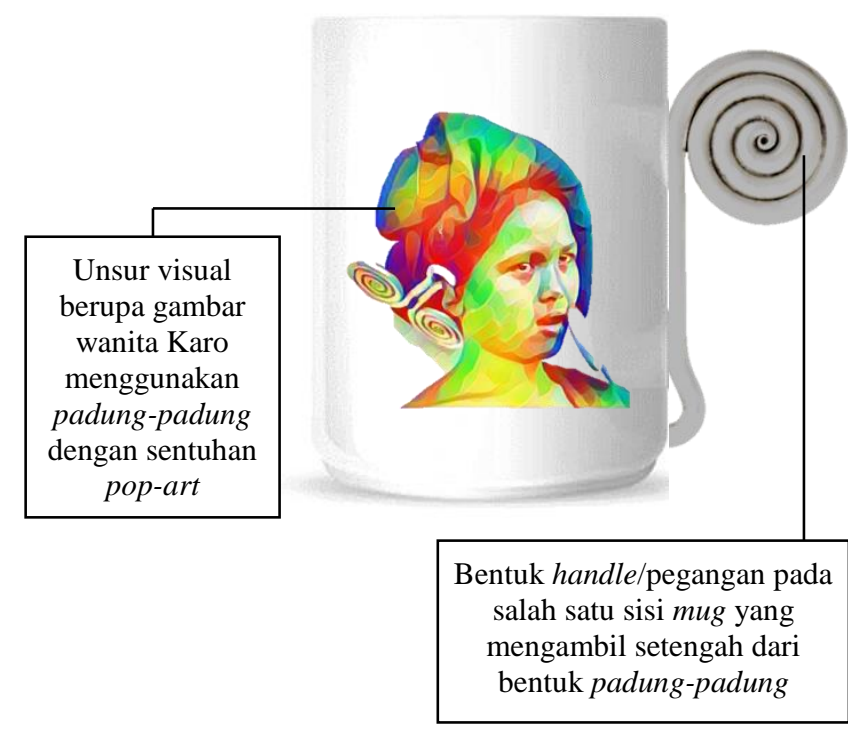

Gambar 8. Alternatif 1 desain mug (Desain oleh Ariani, 2017) 


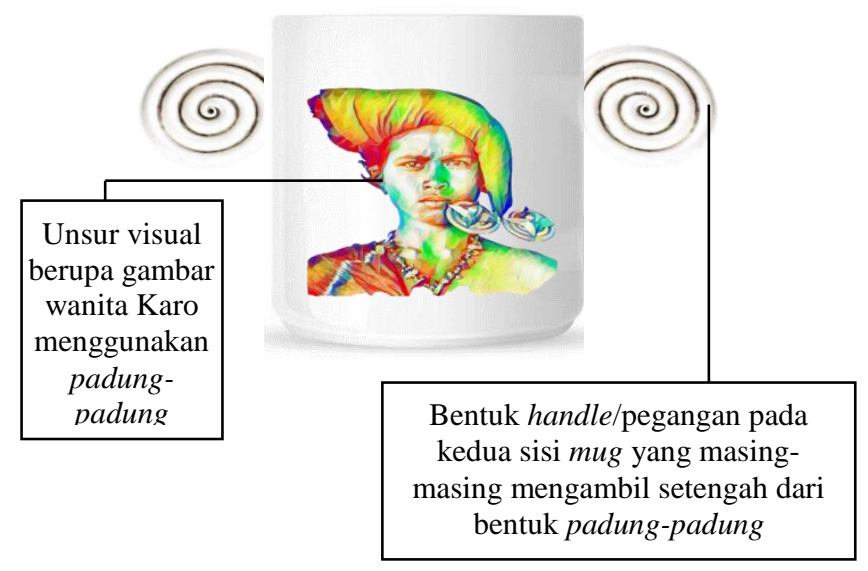

Gambar 8. Alternatif 2 desain mug (Desain oleh Ariani, 2017)

Pada alternatif desain-desain mug di atas, unsur kontemporer ditampilkan melalui desain handle yang simpel dan diadaptasi dari bentuk padung-padung. Sedangkan sebagai unsur visual untuk lebih menonjolkan ciri khas padung-padung ditampilkan dengan gambar wanita Karo yang mengenakan kain penutup kepala dan padung-padung di telinganya.

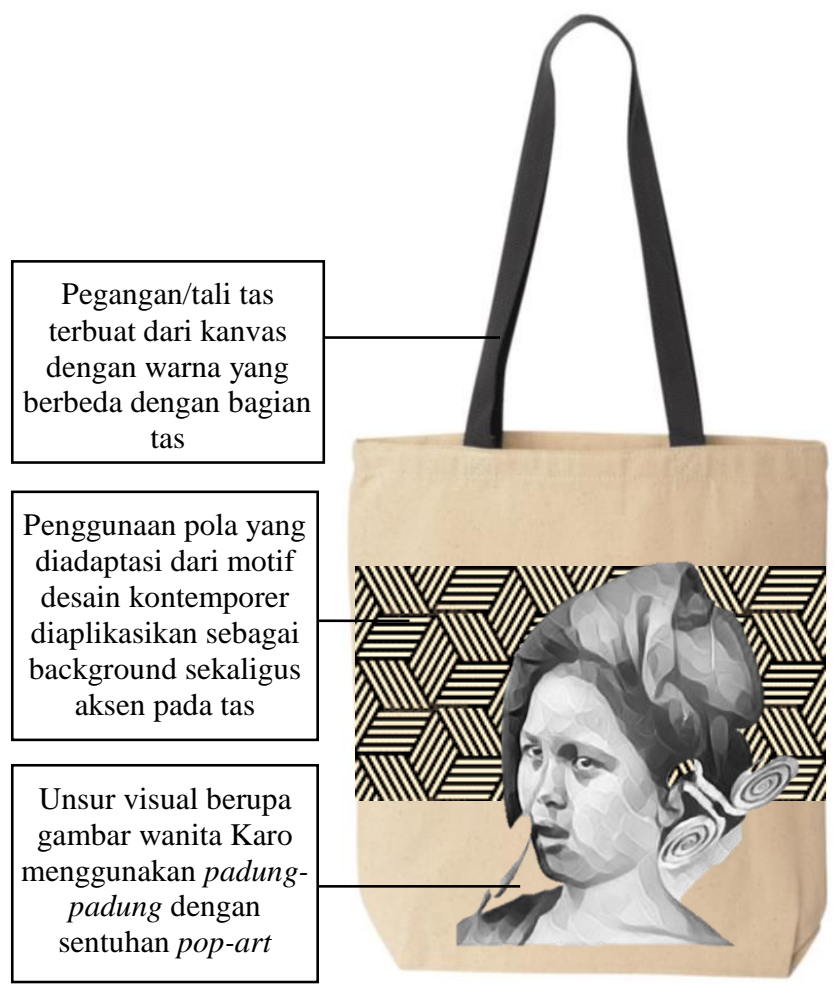

Gambar 9. Contoh desain tas kanvas (tote bag) (Desain oleh Ariani, 2017)

Alternatif desain tas pada Gambar 9 mencoba mengkombinasikan unsur lokal berupa kain (uis) khas suku Karo dengan desain kontemporer yang diwakili oleh unsur visual pop-art. Uis Karo sendiri terdiri dari beragam corak yang masing-masing memiliki makna dan penggunaan yang berbeda. Berikut adalah beberapa visual yang menggambarkan wanita Karo dengan padung-padung di telinganya dalam versi popart.

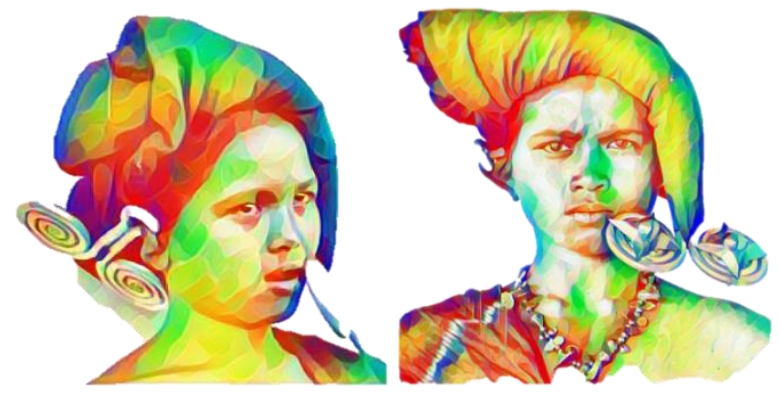

Gambar 10. Padung-padung di telinga dengan gaya pop-art

Beberapa alternatif desain yang telah disampaikan di atas adalah masih sebatas eksperimen yang artinya desain tersebut masih dapat dikembangkan lebih lanjut lagi.

\section{Kesimpulan}

Uraian di atas mendorong penulis untuk menyimpulkan bahwa padung-padung menjadi sebuah perhiasan yang unik karena berat dan ukurannya yang diluar kelaziman sebuah anting-anting pada umumnya. Cara pemakaiannya pun menjadi unik karena harus dikaitkan pada kain penutup kepala untuk mengurangi berat yang harus ditanggung bagian kepala pemakainya. Bentuk padung-padung yang sederhana ternyata menyimpan makna filosofis yang dalam mengenai kebudayaan Karo di masa lalu yaitu tentang kedekatan masyarakat Karo pada alam, kecintaan seorang ayah pada anak gadisnya, dan sikap bijaksana dalam menyikapi naik turunnya kehidupan.

Selain itu, meningkatnya tingkat pendidikan yang dibawa oleh Belanda dan pengaruh agama Kristen di wilayah Karo menyebabkan perubahan dalam cara berpikir masyarakat Karo. Demikian pula modernisasi pasca perang kemerdekaan semakin menggeser budaya lokal yang sebelumnya sangat kental, salah satunya adalah penggunaan padung-padung. Salah satu cara yang dapat kita lakukan untuk menjaga kelestarian padung-padung adalah dengan cara menggali potensi yang ada pada perhiasan itu dan diaplikasikan dalam berbagai produk yang disesuaikan dengan kebutuhan masyarakat di era budaya kontemporer saat ini. 


\section{Daftar pustaka}

Barbier-Muller, Musee \& Rodgers, Susan (1988) Power and Gold: Jewelry from Indonesia, Malaysia and the Philippines from the Collection of the Barbier-Mueller Museum Geneva. UK: Prestel Pub.

Brinkgreve, F., \& D.J. Stuart-Fox (2013) Living with Indonesian Art: The Frits Liefkes Collection, Rijksmuseum Volkenkunde

Cherrington, David J. (1994) Organizational Behavior. United Kingdom: Allyn and Bacon

Cooper, J.C. (1987) Encyclopedia of Traditional Symbols. London, Thames and Hudson

Cuffaro, Daniel F. (2006) Process, Materials, Measurements. United State of America: Rockport Publishers, Inc

Joedawinata, Ahadiat (2010) Materi Perkuliahan Applied Aesthetics, Kuliah Program Magister Desain FSRD Universitas Trisakti, 14 Desember 2010

Ricoeur, Paul (2003) Filsafat Wacana: Membelah Makna dalam Anatomi Bahasa. Yogyakarta: IRCiSoD.

Rodgers, Susan (1988) Power and Gold: Jewelry from Indonesia, Malaysia and the Philippines. USA: Prestel Pub

Siadi, Karo (2010) Wanita Karo (1). Retrieved from https://karosiadi.blogspot.co.id/2010/11/wanita-karo.html accessed 10 November 2015

Sibeth, A. (1991) The Bataks: People of Islands Sumatera. New York: Thames and Hudson

Sitepu, A.G. (2015) Mengenal Seni Kerajinan Tradisional Karo. Medan: BPAD Provinsi Sumatera Utara

Sujarwanto, Afri (2007) Metal Forming Process. Retrieved from https://afrisujarwanto.wordpress.com/2007/09/29/metalforming-process/ accessed 17 Februari 2017.

Sumardjo, Jakob (2006) Estetika Paradoks. Bandung: Sunan Ambu Press 